\title{
INAPPARENT LUNG INVOLVEMENT IN PATIENTS WITH THE SUBACUTE JUVENILE TYPE OF PARACOCCIDIOIDOMYCOSIS
}

\author{
A. RESTREPO, M. TRUJILI, \& I. GOMEZ
}

\begin{abstract}
SUMMARY
Three patients with the diagnosis of subacute juvenile paracoccidioidomycosis who, at the time of their first visit, had no signs or symptoms of lung involvement, were studied. Initially the diagnosis was confirmed by the observation of $\mathbf{P}$. brasiliensis in biopsy material obtained from clinically involved lymphadenopathies.

The lung $\mathrm{X}$-rays done in all patients, did not reveal pathologic changes, although it was possible to observe and isolate the fungus from sputum samples obtained from the three patients. This fact reinforces the pulmonary genesis of the mycosis and proofs the existence of a pulmonary primary infection, even in patients with the juvenile manifestations, in whom the lung component is obscured by the predo minant lymph node involvement.
\end{abstract}

KEY WORDS: Paracoccidioidomycosis; Primary pulmonary infection; Subclinical infection.

\section{INTRODUCTION}

Although the concept of a primary pulmonary form of paracoccidioidomycosis has gained more support in the last decade, there are still some investigators who question this concept $t^{1.58 .13}$. Recently, various publications have informed about patients with spontaneously re gressive forms of pulmonary paracoccidioidomycosis ${ }^{7,9,14}$, which confirm the existence of a pulmonary primary infection. Likewise, there are reports on patients who have undergone im munosupressive therapy for a preexisting ail ment and have, as a result, developed acute or subacute pulmonary paracoccidioidomycosis, although the latter disease had not been pre viously suspected ${ }^{12}$. In these cases, the existence of a subclinical pulmonary form of paracoccidioi- domycosis appears obvious. To further reinforce the primary pulmonary infection, we present 3 patients with the subacute juvenile type of para coccidioidomycosis, in whom clinical evidence of pulmonary infection was lacking in spite of the fact that the causative agent was present in the lungs.

\section{CASE REPORTS}

\section{Case No. 1}

A 5 year-old white boy has had for the last 6 weeks abdominal pain, flatulence, food intolerance and anorexia. A few days after the onset of these symptoms neck pain and odinophagia

Corporación para Investigaciones Biológicas (CIB), Hospital Pablo Tobón Uribe, Medellin, Colombia.

Address for correspondence: Angela Restrepo, Ph. D. Corporación para Investigaciones Biológicas (CIB). Hospital "Pablo Tobón Uribe". Apartado Aéreo No. 73-78, Medellin, Colombia 
RESTREPO, A.; TRUJILLO, M. \& GOMEZ, I. - Inapparent lung involvement in patients with the subacute juvenile type of paracoccidioidomycosis. Rev. Inst. Med. trop. Sāo Paulo, 31 (1): 18 22, 1989.

appeared. In the last 3 days the patient had had fever, frontal headache and diarrhea. In his personal history, his mother recalled several episo des of bronchitis and frequent "colds". There was no history of tuberculosis in the family.

Physical examination revealed a weak, pale but afebrile child. He had tachycardia and weighed only $16 \mathrm{kgs}$. Furthermore, he presented mucopurulent and bilateral rinorrhea and productive cough. Multiple, posterior, cervical lympha denopathies (about $1 \mathrm{~cm}$ in diameter) were felt upon palpation; surgical ressection of one of the se had been performed and the scar was exudative. The examination of the respiratory tract, including auscultation, was normal. In the right periumbilical region, a hard mass $(3 \times 3 \mathrm{cms})$ was palpated. No lesions of the mucous membranes, the pharynx, or the skin were observed. At the time of admission, pertinent laboratory results were as follows: hemoglobin: 7.8, leukocytes: 16.000 , platelets: 794.000 . A bone marrow aspirate obtained a few days before revealed no malignancy. On the other hand, the biopsy of the cervical lymphadenopathy exhibited abundant $\mathbf{P}$. brasiliensis cells. Lung $\mathrm{X}$-rays were informed as normal (Fig. 1). Three sputum samples (easily recovered due to the patient's productive cough), also revealed the fungus in the $\mathrm{KOH}$ mounts; later on, P. brasiliensis was also isola ted in culture from 2 to 3 samples. The serologic tests with paracoccidioidin were non-reactive in the immunodiffusion but titers of 1:256 were de tected in the complement fixation procedure.

With the diagnosis of paracoccidioidomyco sis the child began treatment with itraconazole $150 \mathrm{mgs} /$ day). At the time of this report $(6$ months of therapy), his response is very satisfactory.

\section{Case No. 2}

An 11 year-old boy, student and agricultor in a rural area; the past history revealed seven years of abdominal pain. He was admitted to the hospital with the diagnosis of an intestinal subocclusion and given some treatment with partial improvement. From there on, the child has been ill continously and has been loosing weight. For the last 2 months before the present consultation, several symptoms such as abdo-

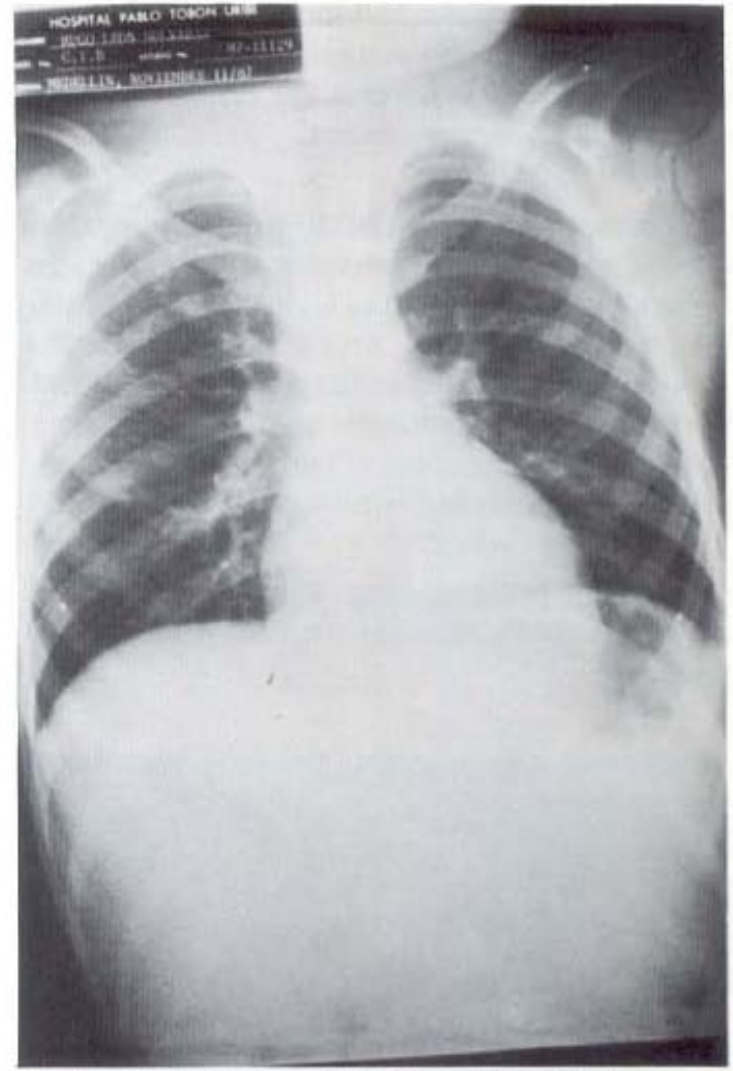

Fig. 1-Clear pulmonary fields. No mediastinal enlargement. normal cardio-aortic outline.

minal pain, vomiting, asthenia, anorexia and fe ver have appeared. He was again hospitalized at the rural setting, but because no improvement was observed, he was transferred to the University Hospital in Medellin, where he was admitted with the diagnosis of peritoneal tuberculosis or non-Hodgkin lymphoma. A biopsy from a cervical lymphadenopathy was performed and the diagnosis of paracoccidioidomycosis was esta. blished.

The physical examination revealed a pale, afebrile patient, with only $19.5 \mathrm{kgs}$ of weight and thin extremities. His hair was scarse and loose. Multiple lymphadenopathies were felt on the neck, inguinal, axillary and epitroclear regions. In the abdomen, the liver was palpated $3 \mathrm{cms}$ below the costal ridge and on percussion it measured $11 \mathrm{cms}$.

The spleen was not palpable. At the same time, a hard, nodular and painful mass was felt 
RESTREFO. A TRUJLLO. M \& GOMEZ. I. ... Inapparent ining involvement in patients with the subacule juvenile type of paracoccidiofiomycosis. Rev. Inst Med trop. Sáo Paulo, 31 (1): 18221989.

in the left side of the abdomen. Lung examination was normal. No lesions were observed on the mucous membranes or the skin the larynx and the pharynx were intact.

Laboratory examinations indicated anemia inemoglobin 9.0 and hematocrit 27 ): leukocytes were elevated (16.500), as well as the sedimentation rate $(95 \mathrm{~mm} / \mathrm{hr}$. An excretory urography showed displacement to the midline of the midportion of the left urether: an abdominal sono. graphy reported a mass of lymphatic origin and echolucid images in the hilium of the liver.

The lurg $x$ rays ifig. 2 , revealed discrete mediastinal enlargement with norrnal lung ap pearance.

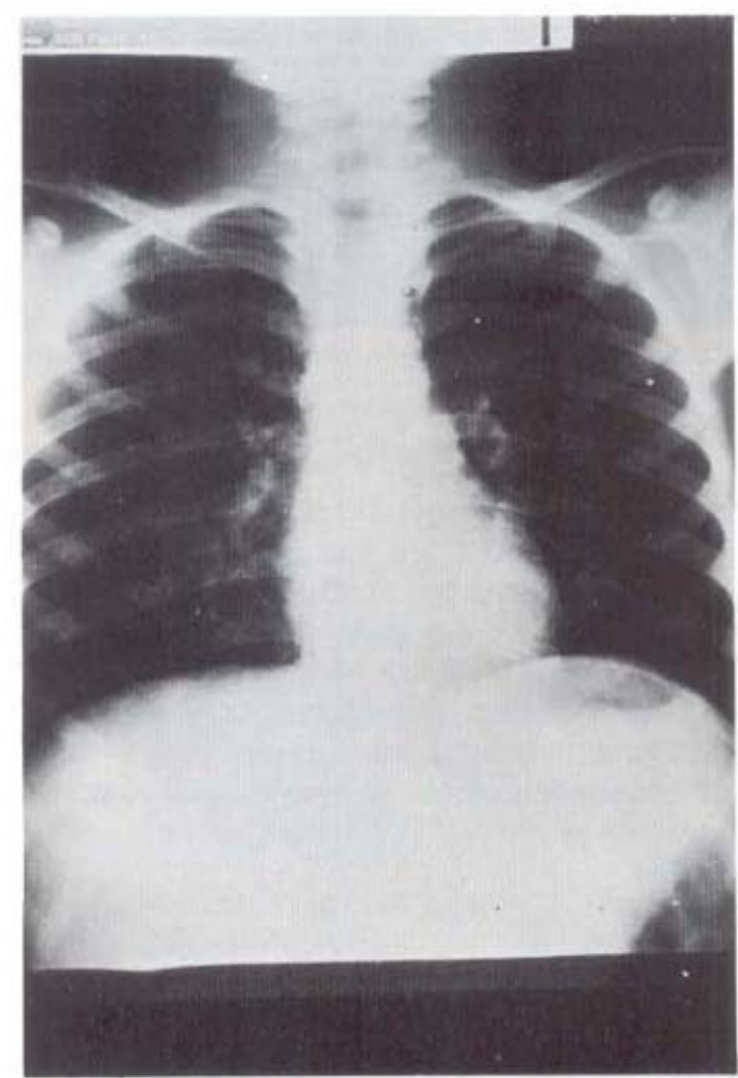

Fig. 2 - Clear pulmonary fields, left mediastinal lobulation. normal cardio-aortic outline.

The patient was nebulized in order to obtain a sputum sample, which on direct examination revealed $\mathbf{P}$. brasiliensis cells; culture also grew the fungus. The serologic tests with paracocci- dioidin showed 2 precipitin bands in the immu nodiffusion test and complement fixation titers of $1: 16$

The patient has been treated 2 years with ketoconazole and has been followed post-therapy for 3 years. His recovery has been satisfactory.

\section{Case No. 3}

A 21 year-old, white male and agricultural worker, searched medical attention because he had had abdominal pain and has noticed abdominal masses for the last 4 and 2 mon ths, respectively. He also complained of anorexia, weight loss, fever, sweating and chills. He was referred from the rural area to the central hospital where a biopsy of a cervical lymphadenopathy was do. ne and $\mathbf{P}$. brasiliensis cells were observed.

Physical examination revealed a patient in poor general conditions, with jaundice and multiple lymphadenopathies in the neck and occipital region. In the abdomen various hard, painful masses were felt which occupied almost all the abdominal cavity. The lungs showed normal ventilation. No mucosal lesions were observed in the oral cavity, nor were skin lesions found.

Among the laboratory tests performed. the following appear important: Hemoglobin: 10.4 g, hematocrit: $34 \%$, leukocytes: 13.400 , sedimentation rate: $51 \mathrm{~mm} / \mathrm{hr}$, platelets: 524.000 . The liver function tests also showed changes; alkaline phosphatases of 537 units.

The lung X-rays were informed as normal (Fig 3). Two induced sputum samples were obtained and $\mathbf{P}$. brasiliensis cells were microscopically detected in both; the culture of one of these samples, grew the fungus. The serologic tests with paracoccidioidin were reactive, one band of precipitate in the agar gel immunodiffusion and titers of 1:1024 in the complement fixation test.

The patients has been treated for 2 years with itraconazole with recovery.

\section{DISCUSSION}

In paracoccidioidomycosis the establishment of the site where the primary infection 
RESTREPO, A.; TRUJILLO, M. \& GOMEZ, I. - Inapparent lung involvement in patients with the subacute juvenile type of paracoccidioidomycosis Rev. Inst. Med trop. Sāo Paulo. 31 (1): 18-22, 1989

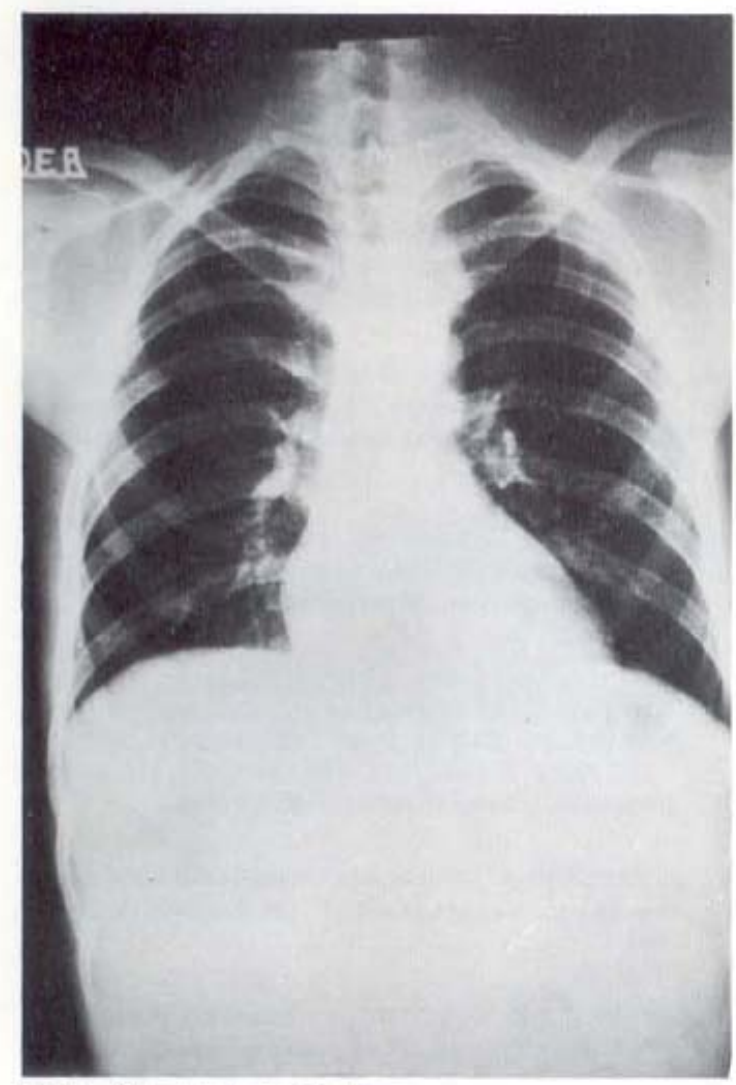

Fig. 3 - No pathological findings

occurs has been a matter of debate because of two basic reasons, as follows: 1 ) the long period of incubation that elapses between the first contact with the fungus and the manifestations of the disease, as has been clearly demonstrated by the cases reported outside of the endemic $\operatorname{areas}^{10} ; 2$ ) the fact that $\mathbf{P}$. brasiliensis has not been consistently recovered from natural sour$\operatorname{ces}^{11}$. At present, however, we believe that there is sufficient evidence to accept the lungs as the primary site of infection. This is demonstrated by the following facts:

Almost $100 \%$ of the autopsy cases have re vealed the presence of paracoccidioidomycotic lesions in the lungs ${ }^{2}, 34.8 \%$ of the active patients present pulmonary involvement as the sole manifestation of the mycosis $430.4 \%$ of those pa tients who seek medical consultation for muco sal and/or skin lesions. if properly examined, ex hibit simultaneous lung involvement $t^{4}$. Newer in formation such as the reports on spontaneously regressive pulmonary forms $s^{9.14}$ and the acute or sub-acute pulmonary forms observed in immunocompromised patients ${ }^{12}$. add more weight to the existence of a primary pulmonary infection in the great majority of patients with pararoccidioidomycosis

As demonstrated by the 3 cases described above, the lack of respiratory symptoms and of radiologic alterations, does not rule out the pre sence of pulmonary colonization with $\mathbf{P}$. brasiliensis. Our patients and another case that has been previously reported ${ }^{10}$, prove that the standard radiologic and physical examinations are insufficient in determining the presence of pul monary alterations. For example, in some pa tients with juvenile paracoccidioidomycosis. LONDERO et al. ${ }^{5}$, found that although some had had initial symptoms related to the gastrointestinal and reticulo-endothelial systems, without radiologic evidence of pulmonary involvement, they had previously manifested pulmonary symptoms. At autopsy, pulmonary lesions were demnnstrated in all of the cases.

More recently, the introduction of new diag nostic techniques in the study of paracoccidiojdomycosis, such as Gallium 67 scintigraphy, have allowed detection of pulmonary lesions which had not been suspected by conventional me thods ${ }^{3}$. Therefore, it seems possible to accept now that the great majority of the patients with this mycosis have or have had (in the case of the spontaneously regressive forms), a primary pulmonary component. As a corollary, it can be stated that in humans the route of infection is inhalatory in most cases. Until the time when P. brasiliensis natural habitat is precisely determined, the information presented above contributes to the improvement of the present model of pathogenesis

\section{RESUMEN}

Compromiso pulmonar inaparente en la forma subaguda juvenil de la paracoccidioidomicosis

Se presentan las historias de 3 pacientes con el diagnóstico de paracoccidioidomicosis juve nil, en los cuales no se demonstraron signos ni sintomas de compromiso pulmonar al momento del diagnóstico. Tal diagnóstico fué inicialmente comprobado por la observación del P. brasilien. 
RESTREPO, A.; TRUJILLO, M. \& GOMEZ, I. - Inapparent lung involvement in patients with the subacute juvenile type of paracoccidioidomycosis. Rev. Inst. Med. trop. São Paulo, 31 (1): 18-22, 1989.

sis en biopsias obtenidas de lesiones ganglionares clinicamente aparentes. Aunque las radiografias de torax no revelaron cambios patológicos en ningún caso, fué posible observar y aislar el hongo de muestras de esputos obtenidas de los tres pacientes. Este hallazgo refuerza la hipótesis de la genesis pulmonar de la paracoccidioidomicosis y comprueba la existencia de una infección primária pulmonar aún en aquellos pacientes que presentan las manifestaciones de la forma juvenil y en quienes el componente pulmonar está disimulado por el gran compromiso de ganglios y órganos linfáticos.

\section{REFERENCES}

1. ALBORNOZ, M. B. \& FUENMAYOR, F. - Cutaneous paracoccidioidomycosis. Rev. Inst. Med. trop. S. Paulo, 25: $82-86,1983$

2. ANGULO-ORTEGA, A. \& POLlak, L. - Paracoccidioi domycosis. In: BAKER, R. D., ed, - The pathological anatomy of the mycoses. Human Infections with fungi, actinomycetes and algae. Berlin, Springer Verlag, 1971. p. $507-560$.

3. GIORGI, M. C.; CAMARGO, E. E.: PINTO, W. P. \& DEL NEGRO, G. - Gallium-67 imaging in the diagnosis of pa racoccidioidomycosis. Europ. J. Nucl, Med., 13: 300 304, 1987

4. GIRALDO, R: RESTREPO, A.: GUTIERREZ, F: RO BLEDO. M.; LONDONO, F.; HERNANDEZ, H.; SUMA, F. \& CALLE, G. - Pathogenesis of paracoccidioidomy cosis: a model band on the study of 46 patients. Mycopathologia (Den Haag). 58: 63-70, 1976

5. LACAZ, C. S. - South American blastomycosis. An. Fac. Med. S, Paulo, 29: 9-120, 1955/1956.

6. LONDERO, A, T,; GONZALEZ, A. T, R.; CRUZ, N. L S.: ROSENBAUM, R.; CUNHA, R. A.; MACHADO, E.E.
VIEIRA, A. R. M.; CARVALHO, F. G.; BRAGA, M. P.; AZEVEDO, E. C. L.; WANKE, B.: CRUZ, M. F. \& MENE ZES, J. A. - Paracoccidioidomicose disseminada "infan to-juvenil" em adolescentes. Relato de quatro casos e revi são da literatura. Arch. bras. Med., 61: 5-12, 1987.

7. LOPEZ, R. \& RESTREPO, A. - Spontaneous regression of pulmonary paracoccidioidomycosis. Report of a case. Mycopathologia (Den Haag) 83: 187-189, 1983.

8. MACHADO-FILHO, J. \& MIRANDA, J. L. - Condiçōes relativas a blastomicose sul-americana: da participação pulmonar em 338 casos consecutivos. Hospital (Rio de J.), 58: $431-449,1960$

9. MELO, I. S. \& LONDERO, A. T. - Spontaneously recovering pulmonary lesions in paracoccidioidomycosis. Case report and review. Mycopathologia (Den Haag), 82: $57-59,1983$

10. RESTREPO, A: ROBLEDO, M: GIRALDO, R: HER NANDEZ, H.; SIERRA, F.; GUTIERREZ, F.; LONDONO, F.; LOPEZ R. \& CALLE, G. - The gamut of paracoccidioidomycosis. Amer, J. Med., 61: 33-42, 1976.

11. RESTREPO, A. - The ecology of Paracoccidioides brasiliensis: a puzzle still unsolved. Sabouraudia, 23: 323-334, 1985

12. SEVERO, L. C.; LONDERO, A. T.; GEYER, G R. \& POR TO, N. S. - Acute pulmonary paracoccidioidomycosis in an immunosuppressed patient. Mycopathologia (Den Haag), 68: 171-174, 1979

13. SILVA, M. S. - Blastomicose pulmonar (paracoccidioidomicosis pulmonar). Rev. bras. Med., 3: 723-729, 1946

14. WANKE, B.; ANDRADE, E. M.; LIMA-NETO, J. A.; \& CRUZ, M. F. F. - Paracoccidioidomicose pulmonar assintomatica e regressiva, com posterior disseminaçāo. Relato de um caso. Rev. Soc. bras. Med. trop., 16:162-167, 1983.

Recebido para publicaçāo em 8/6/1988 